\title{
Juice and Wine Quality Responses of Vitis vinifera L. cvs. Sauvignon blanc and Chenin blanc to Timing of Irrigation during Berry Ripening in the Coastal Region of South Africa
}

\author{
P.A. Myburgh \\ ARC Infruitec-Nietvoorbij*, Private Bag X5026, 7599 Stellenbosch, South Africa \\ Submitted for publication: October 2005 \\ Accepted for publication: February 2006 \\ Key words: Grapevine, irrigation, cations, aroma, fullness, quality.
}

\begin{abstract}
The effects of additional irrigation during berry ripening on juice and wine quality in Sauvignon blanc and Chenin blanc grapevines were investigated. In all treatments the grapevines were irrigated when berries reached pea size in December. One treatment received no further irrigation until after harvest. All of the remaining treatments received a second irrigation at véraison. Except for a single treatment, which was not irrigated during ripening, these treatments received a third irrigation either 14, 21, 28 or 31 days after véraison. The six treatments were applied in a field trial carried out in the Stellenbosch district of the Coastal winegrowing region of South Africa over consecutive seasons, between 1990 and 1993. Irrigation during berry ripening decreased the $\mathbf{N}$ concentration in the juice of both cultivars, but increased the $\mathbf{P}$ and Ca concentrations in the juice, though only in Sauvignon blanc. In neither cultivar were the juice $\mathrm{K}$ and $\mathrm{Mg}$ concentrations affected by irrigation during the ripening period. The irrigation treatments did not affect sugar concentration in Sauvignon blanc grapes. In contrast, sugar concentrations in Chenin blanc grapes that were irrigated 28 days after véraison were lower than in grapes that were irrigated at pea size. Irrigation applied 21 days and 28 days after véraison resulted in higher total titratable acidity in the juice of both cultivars. Irrigation applied 31 days after véraison, i.e. three days before harvest, raised juice $\mathrm{pH}$ in Chenin blanc grapes relative to grapevines that received a single irrigation at pea size. Although not consistent over seasons, irrigation applied during the later stages of ripening had negative effects on fresh vegetative aroma (green pepper, herbaceous or green cut grass flavours) and fullness of Sauvignon blanc wines. Similarly, irrigation during the middle stages of ripening reduced the fermentation character (guava flavour) and fullness of Chenin blanc wines, though not in all seasons. Overall, irrigation during berry ripening tended to reduce wine quality in both cultivars.
\end{abstract}

Wine grapes in the Coastal Region of South Africa are either not irrigated, or receive limited irrigation during the growing season. Since rain mainly falls during winter, high levels of water stress develop in almost all non-irrigated vineyards, particularly during berry ripening (Myburgh, 2005, and references therein). Water deficits during ripening can influence grape composition in more than one way. Plant water stress resulting from water deficits can reduce sugar accumulation (Hardie \& Considine, 1976). Water stress can also decrease total titratable acidity, which can have a negative effect on wine quality (Van Zyl, 1984a). Colouring of Cabernet franc grapes was delayed by severe water stress (Hardie \& Considine, 1976), whereas water stress, as well as luxurious water supply, resulted in poor colouring of Barlinka grapes (Myburgh, 1996). Water relations in grapevines, particularly the effects of water stress indicated by low leaf water potentials $\left(\psi_{1}\right)$, are well documented and reviewed (Smart \& Coombe, 1983; Williams et al., 1994). However, such information does not give rise to the practical irrigation strategies necessary to enable wine quality to be optimised for varying combinations of climate, soil type, and vineyard practice.
Generally, the amount of irrigation water applied to vineyards in the Western Cape Coastal Region depends on water availability, and in this regard the number of irrigations can vary from one to six per season (Van Zyl \& Van Huyssteen, 1983). At bud break, most vineyard soils contain adequate water in the form of stored winter rain to last until flowering (October). Hence, the first irrigation is normally applied after this stage, and is followed by irrigations at pea size (November) and at véraison (January). Although the number and timing of these irrigations were critical with respect to Chenin blanc yield increases, such factors did not have consistent effects on wine quality over seasons as compared with dry land conditions in the Coastal Regions (Van Zyl \& Weber, 1977). In situations where enough water is available to apply more than three irrigations, uncertainty may exist regarding the necessity for, and optimum timing of, such additional irrigations. Due to the warm, dry climatic conditions that normally prevail during mid summer in the Coastal Region, it is likely that the most benefit would be gained by applying the additional irrigation during ripening. It was shown that drip irrigation applied at fortnightly intervals during the six-week period before ripening, 
improved wine quality of Cabernet Sauvignon in comparison to a cutback in irrigation (Hepner et al., 1985). In contrast, water deficits induced during ripening did not reduce wine quality of Colombar compared to continued irrigation (Van Zyl, 1984a). Hence, depending on the specific conditions, it seems that irrigation during ripening can either improve or have no effect on wine quality. Furthermore, it could also be that different cultivars respond differently to irrigation applied during ripening. Unfortunately there is no scientifically based knowledge concerning the effect of irrigation during ripening on wine quality, or the exact amount of water stress required in grapevines to obtain optimum wine quality under the specific climatic, soil and cultivation conditions in the Coastal Region of South Africa.

The aim of this study was to determine the effects of timing of an additional irrigation during ripening on certain juice and wine quality parameters in Sauvignon blanc and Chenin blanc grapevines.

\section{MATERIALS AND METHODS}

\section{Experiment layout}

The field trial was carried out in adjacent seven-year-old Sauvignon blanc/99Richter and nine-year-old Chenin blanc/99Richter vineyards on the Nietvoorbij experiment farm in Stellenbosch. Myburgh (2005) presented details of experimental layout, viticultural practices, climatic conditions and soil properties. Grapevines of all treatments were irrigated when berries reached pea size in December. One treatment (I00) received no further irrigation until harvest, but all the remaining treatments were irrigated at véraison. Except for treatment II0, which was not irrigated during ripening, the treatments received a third irrigation at 14 days (II14), 21 days (II21), 28 days (II28) or 31 days (II31) days after véraison (Table 1). Grapevines in all of the treatments were irrigated once during the post harvest period in March. The six irrigation treatments were applied during the 1990/91, 1991/92 \& 1992/93 seasons. For the purpose of this study, ripening is defined as the period from véraison until harvest. On average, duration of the ripening period was 34 days, which means that the third irrigation was applied at approximately $40 \%, 60 \%, 80 \%$ \& $90 \%$ of ripening for II14, II21, II28 \& II31, respectively. The last irrigation of the II31 treatment was normally applied three days before harvest.

\section{TABLE 1}

Irrigation treatments applied during 1990/91, 1991/92 \& 1992/93 seasons to determine responses of cvs. Sauvignon blanc and Chenin blanc to irrigation during berry ripening at Nietvoorbij, Stellenbosch. ("X" indicates irrigation).

\begin{tabular}{|c|c|c|c|c|c|c|}
\hline \multirow{3}{*}{ Treatment } & \multicolumn{6}{|c|}{ Stage(s) at which irrigation was applied } \\
\hline & \multirow{2}{*}{$\begin{array}{l}\text { Pea size } \\
\text { berries }\end{array}$} & \multirow[t]{2}{*}{ Véraison } & \multicolumn{4}{|c|}{ Days after véraison } \\
\hline & & & 14 & 21 & 28 & 31 \\
\hline $\mathrm{I} 00$ & $X$ & & & & & \\
\hline II0 & $\mathrm{X}$ & $\mathrm{X}$ & & & & \\
\hline III14 & $\mathrm{X}$ & $\mathrm{X}$ & $\mathrm{X}$ & & & \\
\hline II 21 & $X$ & $X$ & & $\mathrm{X}$ & & \\
\hline II 28 & $\mathrm{X}$ & $X$ & & & $\mathrm{X}$ & \\
\hline II31 & $\mathrm{X}$ & $X$ & & & & $X$ \\
\hline
\end{tabular}

\section{Must analyses}

Berries for juice samples were collected in accordance with the procedure described by Myburgh (2005). Berry samples were crushed using a pestle and mortar in such a way that most of the seeds remained intact. Juice samples were filtered through cheesecloth. Total soluble solids (TSS), total titratable acidity (TTA) and $\mathrm{pH}$, as well as cation concentrations, were determined on juice samples from all replications of each treatment using standard Nietvoorbij methods. To determine total $\mathrm{N}$, juice was digested by means of selenium acid and concentrated sulphuric acid. The total $\mathrm{N}$ contents of the digests were then determined using an auto analyser. To determine $\mathrm{P}, \mathrm{K}, \mathrm{Ca}$ and $\mathrm{Mg}$ contents, juice samples were digested by adding concentrated nitric acid to the juice, allowing it to stand overnight and then adding hyperchloric acid. Following the nitric acid/hyperchloric acid digestion, total $\mathrm{P}, \mathrm{K}$, and $\mathrm{Ca}$ values were determined using an inductively coupled plasma atomic emission spectrometer (Liberty 200 ICP AES, Varian, Australia). Since $\mathrm{NaF}$ was added to the juice samples to inhibit fermentation, the $\mathrm{Na}$ concentration was not determined. Sauvignon blanc and Chenin blanc grapes are normally harvested at a TSS:TTA ratio of ca. 2.5. However, due to logistical limitations at the winery, it was not always possible to harvest the grapes at this ratio.

\section{Wine quality}

Wines were prepared from three replications of all treatments of both Sauvignon blanc and Chenin blanc. Forty $\mathrm{kg}$ of grapes were harvested per plot. The grapes were crushed and the free run juice was collected. Total $\mathrm{SO}_{2}$ was adjusted to $70 \mathrm{mg} / \mathrm{L}$. Overnight settling was allowed at $14^{\circ} \mathrm{C}$ after adding $1.5 \mathrm{mg} / \mathrm{L}$ PECTINEX (100x dil.). Clear juice was drawn off into 20-L stainless steel canisters and $80 \mathrm{~g} / \mathrm{hL}$ di-ammonium phosphate added. Juice was inoculated with re-hydrated Saccharomyces cerevisiae (Vin 7) at $40 \mathrm{~g} / \mathrm{hL}$. Fermentation took place at $14^{\circ} \mathrm{C}$. Wines were fermented to dryness, at which point $\mathrm{SO}_{2}$ was adjusted to $40 \mathrm{mg} / \mathrm{L}$, and 50 $\mathrm{g} / \mathrm{hL}$ of bentonite was added. Wines were cold stabilised at $0^{\circ} \mathrm{C}$ for at least one week, then racked and filtered through filter sheets. Free $\mathrm{SO}_{2}$ was adjusted to $30 \mathrm{mg} / \mathrm{L}$ at bottling. Wines were stored in $750-\mathrm{mL}$ bottles at $13^{\circ} \mathrm{C}$ until August, when they were sensorially evaluated by a tasting panel consisting of at least 12 members. A nine-point score card system (Tromp \& Conradie, 1979) was used to evaluate aroma, fullness and overall wine quality. In the case of Sauvignon blanc, the intensity of the fresh vegetative aroma (green pepper, herbaceous or green cut grass flavours) was evaluated, whereas in Chenin blanc the fermentation bouquet (guava flavour) was determined.

\section{Statistical analysis}

The data were subjected to an analysis of variance. Student's t least significant difference (LSD) values were calculated to facilitate comparison between treatment means. Means which differed at $p \leq 0.05$ were considered to be significantly different.

\section{RESULTS AND DISCUSSION}

\section{$\mathrm{N}, \mathrm{P}, \mathrm{K}, \mathrm{Ca}$ and $\mathrm{Mg}$ concentrations in the juice}

Irrigations applied at véraison or during ripening did not affect the $\mathrm{N}$ content of the juice of Sauvignon blanc grapes compared with juice from grapevines that received a single irrigation at pea size (I00) (Table 2). However, an additional irrigation applied 14 days after véraison reduced juice $\mathrm{N}$ compared with irrigation 
applied just before harvest. Although irrigation during ripening produced larger berries compared with a single irrigation at pea size (Myburgh, 2005), smaller berry size could not be related to higher juice $\mathrm{N}$ concentrations. This ruled out the possibility that dilution of the juice occurred when grapevines were irrigated during ripening. In contrast, lower $\mathrm{N}$ concentrations in Chenin blanc grapes coincided with larger berries (Myburgh, 2005) when irrigation was applied 14 days, 21 days and 28 days after véraison, respectively, compared with a single irrigation at pea size. This suggested that irrigation during ripening caused juice dilution in Chenin blanc grapes. When Colombar grapevines were irrigated at $75 \%$ plant available water (PAW) depletion during ripening, cane mass was lower and juice $\mathrm{N}$ higher compared with irrigation at 30\% depletion (Van Zyl, 1984a). However, in spite of consistently lower cane mass, juice $\mathrm{N}$ concentrations were not consistently higher over seasons. Since wetter soil conditions during ripening did not increase cane mass (Myburgh, 2005), lower juice $\mathrm{N}$ levels could not have been caused by increased growth vigour. It was also shown that, although deficit irrigation throughout the growing season reduced cane mass by ca. $50 \%$, juice $\mathrm{N}$ concentration in Bukkettraube grapes did not increase compared with grapevines that received adequate irrigation (Conradie \& Myburgh, 2000).

Water deficits during ripening may cause amino acid accumulation in the juice of water stressed grapevines (Williams \& Matthews, 1990). Water stress significantly increased proline in juice of grapevines compared with juice from continually irrigated grapevines (Matthews \& Anderson, 1988). Hence, where grapevines of the I00 and II0 treatments were subjected to high levels of available water depletion during ripening (Myburgh, 2005), water stress could have increased proline, which is one of the predominating amino acids in Sauvignon blanc and Chenin blanc grapes (Kliewer, 1970). This could also explain the high juice N content in Sauvignon blanc grapes of the II31 treatment, where grapevines were subjected to the same levels of water stress as the II0 treatment for most of the duration of ripening (Myburgh, 2005). Although there is some uncertainty about the exact reason for the lower juice $\mathrm{N}$ content of grapevines that received additional irrigation during ripening, $\mathrm{N}$ concentrations in the juice of the grapes exposed to these treatments were substan- tially higher than levels of $120-140 \mathrm{mg} / \mathrm{L}$ which are required to avoid stuck fermentation (Agenbach, 1977; Spayd et al., 1995). It should be noted that this does not rule out the possibility that lower juice $\mathrm{N}$ levels caused by irrigation during ripening may reduce the rate of fermentation (Conradie \& Louw, 2000). However, under the conditions of this study, no vinification problems were encountered during any of the three seasons.

Juice P concentration in Sauvignon blanc grapes was higher when a third irrigation was applied 14 days after véraison compared with grapes of the two driest treatments (I00 and II0) (Table 2). This suggested that $\mathrm{P}$ uptake and/or subsequent translocation to the berries might have been limited by dry soil conditions. Irrigation applied at véraison, or in combination with an additional irrigation during ripening, did not affect the $\mathrm{P}$ content in Chenin blanc grapes. Irrigation applied at véraison or during ripening did not affect juice $\mathrm{K}$ content of both cultivars in comparison to grapevines that were only irrigated at pea size (Table 2). Likewise, juice K content in Sauvignon blanc grapes did not respond to different irrigation levels during ripening (Naor et al., 1993). In contrast, Matthews \& Anderson (1988) reported more rapid $\mathrm{K}$ accumulation in juice of continually irrigated Cabernet franc grapevines compared with ones that were subjected to water deficits during ripening.

Compared with grapevines that were only irrigated at pea size (I00), juice Ca concentration of Sauvignon blanc was higher when a second irrigation was applied at véraison followed by a third one 21 days later (Table 2). Since the functioning of xylem vessels, which is the only pathway for Ca to flow into berries, normally degenerates after véraison (Lang and Düring, 1991), Ca content in berries generally remains constant during ripening compared with other minerals (Schrader et al., 1976; Maxa et al., 1995; Esteban et al., 1999). However, the Ca content of berries can be reduced during ripening by xylem back flow from berries to other parts of the grapevine (Lang and Thorpe, 1989). Hence, results from the present study suggest that water stress probably reduced the $\mathrm{Ca}$ content in juice of the drier treatments during ripening, rather than $\mathrm{Ca}$ accumulation due to wetter soil conditions. In contrast, it was shown that by increasing berry transpiration artificially, Ca accumulation in berries was increased during ripening, but that $\mathrm{K}$ and $\mathrm{Mg}$ accumulation was almost unaffected (Düring and Oggionni,

\section{TABLE 2}

Effect of irrigation during berry ripening on nitrogen, phosphorus and cation concentration in juice of cvs. Sauvignon blanc and Chenin blanc measured over three seasons at Nietvoorbij, Stellenbosch.

\begin{tabular}{|c|c|c|c|c|c|c|c|c|c|c|}
\hline \multirow{3}{*}{$\begin{array}{l}\text { Treatment } \\
\text { number }^{\mathrm{a}}\end{array}$} & \multicolumn{10}{|c|}{ Cultivar } \\
\hline & \multicolumn{5}{|c|}{ Sauvignon blanc } & \multicolumn{5}{|c|}{ Chenin blanc } \\
\hline & $\begin{array}{c}\mathrm{N} \\
(\mathrm{mg} / \mathrm{L})\end{array}$ & $\begin{array}{c}P \\
(\mathrm{mg} / \mathrm{L})\end{array}$ & $\underset{(\mathrm{mg} / \mathrm{L})}{\mathrm{K}}$ & $\begin{array}{c}\mathrm{Ca} \\
(\mathrm{mg} / \mathrm{L})\end{array}$ & $\begin{array}{c}\mathrm{Mg} \\
(\mathrm{mg} / \mathrm{L})\end{array}$ & $\begin{array}{c}\mathrm{N} \\
(\mathrm{mg} / \mathrm{L})\end{array}$ & $\begin{array}{c}P \\
(\mathrm{mg} / \mathrm{L})\end{array}$ & $\begin{array}{c}\mathrm{K} \\
(\mathrm{mg} / \mathrm{L})\end{array}$ & $\begin{array}{c}\mathrm{Ca} \\
(\mathrm{mg} / \mathrm{L})\end{array}$ & $\begin{array}{c}\mathrm{Mg} \\
(\mathrm{mg} / \mathrm{L})\end{array}$ \\
\hline $\mathrm{I} 00$ & $408 \mathrm{ab}^{\mathrm{b}}$ & $84 \mathrm{~b}$ & $1366 \mathrm{a}$ & $29 \mathrm{~b}$ & $70 \mathrm{a}$ & $466 \mathrm{a}$ & $98 \mathrm{a}$ & $1575 \mathrm{a}$ & $41 \mathrm{a}$ & $75 \mathrm{a}$ \\
\hline II0 & $413 \mathrm{ab}$ & $90 \mathrm{~b}$ & $1383 \mathrm{a}$ & $31 \mathrm{ab}$ & $71 \mathrm{a}$ & $417 \mathrm{ab}$ & 99 a & 1606 a & $44 \mathrm{a}$ & $74 \mathrm{a}$ \\
\hline II14 & $338 \mathrm{~b}$ & $105 \mathrm{a}$ & $1494 \mathrm{a}$ & $34 \mathrm{ab}$ & $77 \mathrm{a}$ & $322 \mathrm{~b}$ & $110 \mathrm{a}$ & $1656 \mathrm{a}$ & $40 \mathrm{a}$ & $77 \mathrm{a}$ \\
\hline II 21 & $353 \mathrm{ab}$ & $92 \mathrm{ab}$ & 1439 a & $38 \mathrm{a}$ & $73 \mathrm{a}$ & $340 \mathrm{~b}$ & $101 \mathrm{a}$ & $1532 \mathrm{a}$ & $40 \mathrm{a}$ & $80 \mathrm{a}$ \\
\hline II 28 & $399 \mathrm{ab}$ & $95 \mathrm{ab}$ & 1399 a & $35 \mathrm{ab}$ & $73 \mathrm{a}$ & $347 \mathrm{~b}$ & $95 \mathrm{a}$ & $1505 \mathrm{a}$ & $41 \mathrm{a}$ & $71 \mathrm{a}$ \\
\hline II31 & $445 \mathrm{a}$ & $92 \mathrm{ab}$ & $1398 \mathrm{a}$ & $33 \mathrm{ab}$ & $72 \mathrm{a}$ & $371 \mathrm{ab}$ & $99 \mathrm{a}$ & $1644 \mathrm{a}$ & $40 \mathrm{a}$ & $76 a$ \\
\hline
\end{tabular}

a Refer to Table 1 for explanation of treatments.

b Values designated by the same letter within each column do not differ significantly $(p \leq 0.05)$. 
1986). Furthermore, it was found under field conditions that xylem flow, although small and sometimes negative, can occur during ripening (Greenspan et al., 1996). This suggests that wetter soil conditions could have induced higher berry transpiration rates leading to increased $\mathrm{Ca}$ accumulation in comparison to berries that were subjected to water stress. The various irrigation treatments did not affect juice $\mathrm{Mg}$ concentration of the two cultivars. Similarly, juice $\mathrm{Mg}$ concentration of non-irrigated Tempranillo grapevines did not differ compared with ones that were drip-irrigated daily (Esteban et al., 1999).

\section{TSS, TTA \& pH}

Although the mean yield of Sauvignon blanc was approximately $13 \mathrm{t} /$ ha during the 1992/93 season compared with $9 \mathrm{t} / \mathrm{ha}$ in the first two seasons (Myburgh, 2005), the higher yield did not restrict the rate of berry ripening. Naor et al. (1993) reported a similar yield variation between seasons for Sauvignon blanc, but concluded that sugar accumulation was lower during seasons when yields were in the order of $30 \mathrm{t} / \mathrm{ha}$, compared with seasons when yields were less that $20 \mathrm{t} / \mathrm{ha}$. Irrigation at véraison, as well as an additional irrigation applied at any stage during ripening, did not affect sugar accumulation in Sauvignon blanc grapes compared with those that were irrigated only at pea size berries (Table 3). As a consequence, grapes from all treatments could be harvested on the same day during the three seasons. Irrigation continued at $30 \%$ plant available water depletion during ripening also did not affect sugar accumulation in Colombar (Van Zyl, 1984b) and Sultanina (Myburgh, 2003) compared with grapevines that were subjected to water deficits. In contrast, low levels of drip irrigation during ripening, i.e. $1 \mathrm{~mm} /$ day, resulted in lower sugar content in Sauvignon blanc grapes bearing a crop load in excess of $17 \mathrm{t} / \mathrm{ha}$, compared with an irrigation applied at a rate of $3.5 \mathrm{~mm} /$ day (Naor et al., 1993). Irrigation applied to Chenin blanc 28 days after véraison, i.e. one week before harvest, reduced TSS in comparison to juice of the II0, II14 and II21 treatments. This effect was probably due to dilution caused by the entry into the berries of disproportionately more water than sugar.

Irrigation applied at véraison in combination with an additional irrigation, either applied 21 days or 28 days after véraison, caused higher TTA in Sauvignon blanc and Chenin blanc grapes compared with the juice of grapevines that were only irrigated at pea size (Table 3). This observation agrees with earlier findings that dry soil conditions lead to increased TTA breakdown compared with higher levels of soil water availability (Van Zyl, 1984b; Myburgh, 1996). A possible dilution effect, in combination with water deficits during ripening, probably caused lower TTA in grapes that were irrigated three days before harvest (II31) compared with the II 21 and II28 treatments. In instances where Sauvignon blanc grapevines were irrigated daily, a low irrigation level during ripening only reduced TTA in one out of the four seasons (Naor et al., 1993). Additional irrigations applied at véraison and during ripening did not affect the TSS to TTA ratio of either cultivar, compared with a single irrigation at pea size, during any of the seasons (Table 3). Irrigation applied at véraison and an additional irrigation during ripening did not affect the juice $\mathrm{pH}$ of Sauvignon blanc compared with a single irrigation applied at pea size (Table 3). The juice $\mathrm{pH}$ of Colombar grapevines that were subjected to water deficits during ripening also did not differ from those that were irrigated up to harvest (Van Zyl, 1984b). Similarly, the juice $\mathrm{pH}$ of drip-irrigated Sauvignon blanc was also relatively insensitive to different irrigation levels during ripening (Naor et al., 1993). In contrast, the juice $\mathrm{pH}$ of Chenin blanc that received irrigation three days before harvest was higher compared with those that were irrigated once at pea size.

\section{Wine quality}

In general, the intensity of the fresh vegetative aroma (green pepper, herbaceous or green cut grass flavours) in Sauvignon blanc wines did not differ between seasons (Table 4). This result was to be expected since ambient air temperature of the ripening period, which can affect the aroma intensity and flavour composition of Sauvignon wines (Marais et al., 1999; Bonnardot et al., 2000), did not differ between seasons (Myburgh, 2005). Mean air temperatures during the ripening period were also comparable to the long term mean of $27.9^{\circ} \mathrm{C}$. Higher crop loads during the $1992 / 93$ season (Myburgh, 2005) did not affect the mean fresh vegetative aroma intensity compared with the first two seasons. Additional irrigation at véraison and during ripening did not affect the intensity of the fresh vegetative aroma compared with a single irrigation at pea size during the first two seasons (Table 4). In the 1992/93 season, however, irrigation applied three days before harvest (II31) resulted in a less prominent fresh vegetative aroma

\section{TABLE 3}

Effect of irrigation during berry ripening on total soluble solids (TSS), total titratable acids (TTA) and pH in juice of cvs. Sauvignon blanc and Chenin blanc measured over three seasons at Nietvoorbij, Stellenbosch.

Cultivar

\begin{tabular}{|c|c|c|c|c|c|c|c|c|}
\hline \multirow{2}{*}{$\begin{array}{l}\text { Treatment } \\
\text { number }\end{array}$} & \multicolumn{4}{|c|}{ Sauvignon blanc } & \multicolumn{4}{|c|}{ Chenin blanc } \\
\hline & $\begin{array}{l}\text { TSS } \\
\left({ }^{\circ} \mathbf{B}\right)\end{array}$ & $\begin{array}{l}\text { TTA } \\
(\mathrm{g} / \mathrm{L})\end{array}$ & TSS : TTA & pH & $\begin{array}{l}\text { TSS } \\
\left({ }^{\circ} \mathbf{B}\right)\end{array}$ & $\begin{array}{l}\text { TTA } \\
(\mathrm{g} / \mathrm{L})\end{array}$ & TSS : TTA & pH \\
\hline $\mathrm{I} 00$ & $22.6 \mathrm{a}^{\mathrm{b}}$ & $8.4 \mathrm{~b}$ & $2.7 \mathrm{a}$ & $3.25 \mathrm{a}$ & $22.2 \mathrm{ab}$ & $7.6 \mathrm{~b}$ & $2.9 \mathrm{a}$ & $3.25 \mathrm{~b}$ \\
\hline IIO & $23.1 \mathrm{a}$ & $8.7 \mathrm{ab}$ & $2.7 \mathrm{a}$ & $3.28 \mathrm{a}$ & $22.8 \mathrm{a}$ & $7.7 \mathrm{ab}$ & $3.0 \mathrm{a}$ & $3.32 \mathrm{ab}$ \\
\hline II14 & $23.2 \mathrm{a}$ & $8.7 \mathrm{ab}$ & $2.7 \mathrm{a}$ & $3.29 \mathrm{a}$ & $22.9 \mathrm{a}$ & $7.9 \mathrm{ab}$ & $2.9 \mathrm{a}$ & $3.36 \mathrm{ab}$ \\
\hline II 21 & $23.2 \mathrm{a}$ & $9.1 \mathrm{a}$ & $2.6 \mathrm{a}$ & $3.26 \mathrm{a}$ & $22.9 \mathrm{a}$ & $8.2 \mathrm{a}$ & $2.8 \mathrm{a}$ & $3.36 \mathrm{ab}$ \\
\hline II 28 & $22.7 \mathrm{a}$ & $9.1 \mathrm{a}$ & $2.5 \mathrm{a}$ & $3.27 \mathrm{a}$ & $21.7 \mathrm{~b}$ & $8.1 \mathrm{a}$ & $2.7 \mathrm{a}$ & $3.36 \mathrm{ab}$ \\
\hline II31 & $23.3 \mathrm{a}$ & $8.3 \mathrm{~b}$ & $2.8 \mathrm{a}$ & $3.30 \mathrm{a}$ & $22.1 \mathrm{ab}$ & $7.5 \mathrm{~b}$ & $2.9 \mathrm{a}$ & $3.37 \mathrm{a}$ \\
\hline
\end{tabular}

a Refer to Table 1 for explanation of treatments.

b Values designated by the same letter within each column do not differ significantly $(p \leq 0.05)$. 
compared with grapevines that received a single irrigation at pea size (I00). This showed that a decrease in $\psi_{1}$ from ca. $-1 \mathrm{MPa}$ to -1.3 MPa (Myburgh, 2005) could increase the fresh vegetative aroma intensity of Sauvignon blanc wine. The possibility that the higher yields during this particular season contributed to the effect of irrigation should not be ruled out. Although lower water stress could have negative effects on this particular aroma, the effect of water deficits might not be as pronounced or consistent as the effect of ambient temperature due to differences between localities (Marais et al., 1999) or seasons (Bonnardot et al., 2000). As in the case of Sauvignon blanc, the fermentation bouquet (guava flavour) of Chenin blanc did not differ between seasons (Table 4). The response of the fermentation bouquet also appeared to be relatively insensitive to irrigation applied during berry ripening and to be inconsistent over seasons. The intensity of the Chenin blanc fermentation bouquet was only lower in wine made from grapes that received a third irrigation 14 days after véraison compared with the II28 and II31 treatments during the 1990/91 season (Table 4).

In general, fullness of the Sauvignon blanc wines did not differ between seasons (Table 5). During the 1990/91 season, a second irrigation applied at pea size (II0) resulted in less fuller Sauvignon blanc wine compared with wine made from grapes that received only one irrigation at pea size (I00) (Table 5). Since wine fullness of one of the replications of the I00 treatment was exceptionally high, an error during vinification could have caused the high mean value. In general, irrigation applied three days before harvest (II31) increased the fullness of the Sauvignon blanc wines compared with those that received only two irrigations. However, according to comments by the tasting panel members, this fullness was not typical for Sauvignon blanc wine, and caused a rather negative than positive impression of the wines. Fullness of the Chenin blanc wines also did not differ between seasons (Table 5). As in the case of Sauvignon blanc, irrigation of Chenin blanc close to harvest resulted in fuller wines compared with the II0 and II21 treatments, but this did not seem to cause any negative impressions.

As was the case for wine character and fullness, overall wine quality did not differ between seasons in general (Table 6). Although $\psi_{1}$ in Sauvignon blanc grapevines that received only one irrigation at pea size was lower than -1.2 MPa at harvest (Myburgh, 2005), overall wine quality was not affected compared with treatments where $\psi_{1}$ was higher. Furthermore, timing of an additional irrigation during ripening did not affect overall wine quality compared with a single irrigation at pea size during any of the three seasons. Since wine quality tended to be reduced by irrigation during ripening, par-

\section{TABLE 4}

Effect of irrigation during berry ripening on wine cultivar character of cvs. Sauvignon blanc and Chenin blanc measured over three seasons at Nietvoorbij, Stellenbosch.

\begin{tabular}{|c|c|c|c|c|c|c|c|c|}
\hline \multirow{3}{*}{$\begin{array}{l}\text { Treatment } \\
\text { number }^{\mathrm{a}}\end{array}$} & \multicolumn{8}{|c|}{ Cultivar character ${ }^{b}$} \\
\hline & \multicolumn{4}{|c|}{ Sauvignon blanc } & \multicolumn{4}{|c|}{ Chenin blanc } \\
\hline & 1990/91 & 1991/92 & $1992 / 93$ & Mean & 1990/91 & 1991/92 & $1992 / 93$ & Mean \\
\hline $\mathrm{I} 00$ & $6.2 \mathrm{a}^{\mathrm{c}}$ & $5.3 \mathrm{a}$ & $6.4 \mathrm{a}$ & $6.0 \mathrm{a}$ & $5.2 \mathrm{ab}$ & $4.6 \mathrm{a}$ & $5.2 \mathrm{a}$ & $5.0 \mathrm{a}$ \\
\hline II0 & $3.9 \mathrm{a}$ & $5.5 \mathrm{a}$ & $4.9 \mathrm{ab}$ & $4.8 \mathrm{a}$ & $5.1 \mathrm{ab}$ & $5.1 \mathrm{a}$ & $5.1 \mathrm{a}$ & $5.1 \mathrm{a}$ \\
\hline II14 & $4.9 \mathrm{a}$ & $5.0 \mathrm{a}$ & $5.5 \mathrm{ab}$ & $5.1 \mathrm{a}$ & $3.8 \mathrm{~b}$ & $4.8 \mathrm{a}$ & $5.1 \mathrm{a}$ & $4.6 \mathrm{a}$ \\
\hline II 21 & $5.0 \mathrm{a}$ & $4.8 \mathrm{a}$ & $4.6 \mathrm{ab}$ & $4.8 \mathrm{a}$ & $4.4 \mathrm{ab}$ & $5.0 \mathrm{a}$ & $5.1 \mathrm{a}$ & $4.8 \mathrm{a}$ \\
\hline II 28 & $5.7 \mathrm{a}$ & $5.1 \mathrm{a}$ & $4.7 \mathrm{ab}$ & $5.2 \mathrm{a}$ & $5.3 \mathrm{a}$ & $5.6 \mathrm{a}$ & $5.3 \mathrm{a}$ & $5.4 \mathrm{a}$ \\
\hline II31 & $4.4 \mathrm{a}$ & $4.2 \mathrm{a}$ & $3.6 \mathrm{~b}$ & $4.1 \mathrm{a}$ & $6.1 \mathrm{a}$ & $5.3 \mathrm{a}$ & $4.6 \mathrm{a}$ & $5.3 \mathrm{a}$ \\
\hline
\end{tabular}

${ }^{\text {a }}$ Refer to Table 1 for explanation of treatments.

b Green pepper, herbaceous or green cut grass for Sauvignon blanc and fermentation bouquet (guava flavour) for Chenin blanc.

c Values designated by the same letter within each column do not differ significantly $(\mathrm{p} \leq 0.05)$.

\section{TABLE 5}

Effect of irrigation during berry ripening on wine fullness of cvs. Sauvignon blanc and Chenin blanc measured over three seasons at Nietvoorbij, Stellenbosch.

\begin{tabular}{|c|c|c|c|c|c|c|c|c|}
\hline \multirow{3}{*}{$\begin{array}{l}\text { Treatment } \\
\text { number }\end{array}$} & \multicolumn{8}{|c|}{ Wine fullness } \\
\hline & \multicolumn{4}{|c|}{ Sauvignon blanc } & \multicolumn{4}{|c|}{ Chenin blanc } \\
\hline & 1990/91 & 1991/92 & $1992 / 93$ & Mean & $1990 / 91$ & 1991/92 & $1992 / 93$ & Mean \\
\hline $\mathrm{I} 00$ & $6.3 \mathrm{a}^{\mathrm{b}}$ & $4.6 \mathrm{a}$ & $4.3 \mathrm{a}$ & $5.1 \mathrm{ab}$ & $4.9 \mathrm{a}$ & $5.1 \mathrm{a}$ & $4.6 \mathrm{a}$ & $4.9 \mathrm{ab}$ \\
\hline IIO & $3.8 \mathrm{~b}$ & $5.0 \mathrm{a}$ & $4.7 \mathrm{a}$ & $4.5 \mathrm{~b}$ & $4.6 \mathrm{a}$ & $4.9 \mathrm{a}$ & $4.6 \mathrm{a}$ & $4.7 \mathrm{~b}$ \\
\hline II14 & $4.9 \mathrm{ab}$ & $4.5 \mathrm{a}$ & $5.1 \mathrm{a}$ & $4.8 \mathrm{ab}$ & $5.3 \mathrm{a}$ & $5.4 \mathrm{a}$ & $5.0 \mathrm{a}$ & $5.2 \mathrm{ab}$ \\
\hline II 21 & $4.1 \mathrm{ab}$ & $5.1 \mathrm{a}$ & $4.9 \mathrm{a}$ & $4.7 \mathrm{ab}$ & $4.4 \mathrm{a}$ & $4.9 \mathrm{a}$ & $4.9 \mathrm{a}$ & $4.7 \mathrm{~b}$ \\
\hline II 28 & $5.5 \mathrm{ab}$ & $5.3 \mathrm{a}$ & $5.5 \mathrm{a}$ & $5.4 \mathrm{ab}$ & $4.7 \mathrm{a}$ & $4.8 \mathrm{a}$ & $5.4 \mathrm{a}$ & $5.0 \mathrm{ab}$ \\
\hline III 1 & $5.6 \mathrm{ab}$ & $5.1 \mathrm{a}$ & $6.0 \mathrm{a}$ & $5.5 \mathrm{a}$ & $6.2 \mathrm{a}$ & $5.6 \mathrm{a}$ & $5.2 \mathrm{a}$ & $5.7 \mathrm{a}$ \\
\hline
\end{tabular}

a Refer to Table 1 for explanation of treatments.

${ }^{b}$ Values designated by the same letter within each column do not differ significantly $(\mathrm{p} \leq 0.05)$. 
TABLE 6

Effect of irrigation during berry ripening on wine quality of cvs. Sauvignon blanc and Chenin blanc measured over three seasons at Nietvoorbij, Stellenbosch.

\begin{tabular}{|c|c|c|c|c|c|c|c|c|}
\hline \multirow{3}{*}{$\begin{array}{l}\text { Treatment } \\
\text { number }^{\mathrm{a}}\end{array}$} & \multicolumn{8}{|c|}{ Wine quality } \\
\hline & \multicolumn{4}{|c|}{ Sauvignon blanc } & \multicolumn{4}{|c|}{ Chenin blanc } \\
\hline & $1990 / 91$ & $1991 / 92$ & $1992 / 93$ & Mean & $1990 / 91$ & 1991/92 & $1992 / 93$ & Mean \\
\hline $\mathrm{I} 00$ & $5.3 \mathrm{a}^{\mathrm{b}}$ & $4.8 \mathrm{a}$ & $6.2 \mathrm{a}$ & $5.4 \mathrm{a}$ & $5.0 \mathrm{a}$ & $5.1 \mathrm{a}$ & $5.3 \mathrm{a}$ & $5.1 \mathrm{a}$ \\
\hline IIO & $4.4 \mathrm{a}$ & $5.2 \mathrm{a}$ & $5.5 \mathrm{a}$ & $5.0 \mathrm{a}$ & $5.2 \mathrm{a}$ & $5.2 \mathrm{a}$ & $4.5 \mathrm{a}$ & $5.0 \mathrm{a}$ \\
\hline II14 & $5.2 \mathrm{a}$ & $5.1 \mathrm{a}$ & $4.4 \mathrm{a}$ & $4.9 \mathrm{a}$ & $4.4 \mathrm{a}$ & $5.0 \mathrm{a}$ & $4.9 \mathrm{a}$ & $4.8 \mathrm{a}$ \\
\hline II 21 & $4.6 \mathrm{a}$ & $5.0 \mathrm{a}$ & $4.5 \mathrm{a}$ & $4.7 \mathrm{a}$ & $4.5 \mathrm{a}$ & $4.7 \mathrm{a}$ & $4.9 \mathrm{a}$ & $4.7 \mathrm{a}$ \\
\hline II 28 & $5.3 \mathrm{a}$ & $5.2 \mathrm{a}$ & $4.5 \mathrm{a}$ & $5.0 \mathrm{a}$ & $5.3 \mathrm{a}$ & $5.1 \mathrm{a}$ & $5.4 \mathrm{a}$ & $5.3 \mathrm{a}$ \\
\hline II31 & $5.2 \mathrm{a}$ & $4.4 \mathrm{a}$ & $4.4 \mathrm{a}$ & $4.7 \mathrm{a}$ & $5.6 \mathrm{a}$ & $5.1 \mathrm{a}$ & $4.9 \mathrm{a}$ & $5.2 \mathrm{a}$ \\
\hline
\end{tabular}

${ }^{a}$ Refer to Table 1 for explanation of treatments.

b Values designated by the same letter within each column do not differ significantly $(\mathrm{p} \leq 0.05)$.

ticularly when applied close to harvest, it could be that a combination of the negative effects on fresh vegetative aroma and atypical fullness of the wines caused this trend. Likewise, irrigation applied 14 days and 21 days after véraison only tended to reduce overall wine quality of Chenin blanc (Table 6). The insensitivity of overall wine quality to irrigation applied during ripening agreed with results reported for Colombar (Van Zyl, 1984a). However, it does not rule out the possibility that the wine quality of other cultivars, e.g. Cabernet Sauvignon (Hepner et al., 1985), might respond more readily to different irrigation strategies during ripening.

\section{Timing of irrigation before harvest}

Considering the levels of PAW depletion that grapevines were subjected to (Myburgh, 2005), and the risk of negative effects on wine quality parameters caused by irrigation during ripening, as discussed above, the last irrigation before harvest should be scheduled in such a way that $90 \%$ of the PAW would be depleted when the grapes are ripe. In the case of vineyards on sandy soils, or where roots are shallower than $0.6 \mathrm{~m}$, as well as where drip irrigation limits root distribution, grapevines will be less buffered against water stress during heat waves compared with those having well developed, deep root systems on loamy or clay soils (Myburgh et al., 1996). Hence, it is suggested that only $80 \%$ available water depletion should be allowed when available water in the root zone is limited. The time required for sufficient water depletion between the last irrigation and harvest can be estimated by the following equation:

$\mathrm{t}=(\mathrm{PAW} \times \mathrm{d}) \times(\mathrm{DL} \div 100) \div\left(\mathrm{k}_{\mathrm{pan}} \times \mathrm{E}_{\mathrm{pan}}\right)$

where: $\mathrm{t}$ is the period before harvest (days), PAW is the plant available water $(\mathrm{mm} / \mathrm{m}), \mathrm{d}$ is the root depth $(\mathrm{m}), \mathrm{DL}$ is the soil water depletion level (\%), $\mathrm{k}_{\mathrm{pan}}$ is the crop coefficient and $\mathrm{E}_{\mathrm{pan}}$ is the long-term mean American Class-A pan evaporation (mm/day) for the specific locality. For vineyards with well developed root systems on heavier soils, where additional irrigation during ripening would be unlikely, $\mathrm{k}_{\mathrm{pan}}$ should be 0.3 according to data presented by Van Zyl \& Weber (1981) and Myburgh (2005). In cases where limited available water would require an additional irrigation during ripening, which would increase evapotranspiration (Myburgh, 2005), $\mathrm{k}_{\mathrm{pan}}$ should be 0.5 for frequently irrigated vineyards, as proposed by Van Zyl \& Fourie (1988).

The use of Equation 1 is demonstrated by the following examples: Where a vineyard in loamy soil has a root depth of $0.9 \mathrm{~m}$ at a locality where the long term mean $\mathrm{E}_{\mathrm{pan}}$ is $9.5 \mathrm{~mm} / \mathrm{day}$, and the plant available water is $120 \mathrm{~mm} / \mathrm{m}$, the last irrigation should be applied 34 days before harvest to allow $90 \%$ PAW depletion when the grapes are picked. In practice, the length of this period implies that irrigation would not be necessary during ripening. For a vineyard under the same conditions, but where poor soil conditions restricts the root depth to $0.6 \mathrm{~m}$, the last irrigation should be applied 12 days before harvest to allow 80\% PAW depletion. For practical purposes this means that irrigation would be necessary during berry ripening. In Burgundy it was found that air temperatures above the normal advanced ripening of Pinot noir by about ten days and that lower temperatures had the opposite effect (Bonnardot, 1997). Coombe (1992) also showed that variation in climatic conditions between seasons affect the onset of véraison, as well as the rate of ripening and the time that full ripeness is attained. Since the duration of berry ripening can vary between seasons, the timing of the last irrigation before ripening will depend on the climatic conditions during a specific season. Furthermore, it would be almost impossible to predict the climatic conditions for the entire ripening period. Consequently, the estimated timing of the last irrigation before harvest should merely be considered as a guideline to determine if irrigation during ripening would be necessary.

\section{CONCLUSIONS}

Under the conditions of this field trial, irrigation during berry ripening did not have a consistent effect on juice composition or wine quality of either Sauvignon blanc or Chenin blanc. Results showed that irrigation applied during the later stages of ripening could have negative effects on wine aroma or fullness, which might increase the risk of reduced overall wine quality. Furthermore, it was shown that water stress in grapevines, i.e. $\psi_{1}$ values of ca. $-1.5 \mathrm{MPa}$, was not detrimental to wine quality. However, this might not be the case in vineyards on soils where plant available water is limited due to sandy soil texture or where root systems are either restricted by soil physical limitations or partial soil wetting under drip irrigation. Further research is needed to address these aspects.

\section{LITERATURE CITED}

Agenbach, W.A., 1977. A study of must nitrogen content in relation to incomplete fermentation, yeast production and fermentation activity. Proc. 5th S. Afr. Soc. Enol. Vitic. Congress, November 1977, Cape Town, South Africa. pp. 66-88. 
Bonnardot, V., Carey, V. \& Schmidt, A., 2000. The effect of vintage and location on Sauvignon blanc wines aroma in the Stellenbosch-Klein Drakenstein winegrowing area (Vintages 1996-1999). Wynboer October 2000, 10-14.

Bonnardot, V., 1997. Some climatic indices for Pinot noir maturation at a meteorological station in Burgundy. S. Afr. J. Enol. Vitic. 18, 19-23.

Coombe, B.G., 1992. Research on development and ripening of the grape berry. Am. J. Enol. Vitic. 43, 101-110.

Conradie, W.J. \& Myburgh, P.A., 2000. Fertigation of Vitis vinifera L. cv. Bukketttraube/110 Richter on a sandy soil. S. Afr. J. Enol. Vitic. 21, 40-47.

Conradie, W.J. \& Louw, P.J.E., 2000. Effect of soil type and nitrogen fertilization on nitrogen content of must and fermentation rate. Proc. 25th World Vine and Wine Congress, June 2000, Paris, France.

Düring, H. \& Oggionni, F., 1986. Transpiration und Mineralstoffeinlagerung der Weinbeere. Vitis 25, 59-66.

Esteban, M., Villanueva, J. \& Lissarrague, J.R., 1999. Effect of changes in berry composition of Tempranillo during maturation. Sugars, organic acids, and mineral elements. Am. J. Enol. Vitic. 50, 418-434.

Greenspan, M.D., Schultz, H.R. \& Matthews, M.A., 1996. Field evaluation of water transport in grape berries during water deficits. Physiol. Plant. 97, 55-62.

Hardie, W.J. \& Considine, J.A., 1976. Response of grapes to water-deficit stress in particular stages of development. Am. J. Enol. Vitic. 27, 55-61.

Hepner, Y., Bravdo, B., Loinger, C., Cohen, S. \& Tabacman, H., 1985. Effect of drip irrigation schedules on growth, yield, must composition and wine quality of Cabernet Sauvignon. Am. J. Enol. Vitic. 36, 77-85.

Kliewer, W.M., 1970. Free amino acids and nitrogenous fractions in wine grapes. J. Food Sci. 35, 17-21.

Lang, A. \& Thorpe, M.R., 1989. Xylem, phloem and transpiration flows in a grape: Application of a technique for measuring the volume of attached fruits to high resolution using Archimedes' principle. J. Exp. Bot. 40, 1069-1078.

Lang, A. \& Düring, H., 1991. Partitioning control by water potential gradient: Evidence for compartmentation breakdown in grape berries. J. Exp. Bot. 42, $1117-1122$

Marais, J., Hunter, J.J. \& Haasbroek, P.D., 1999. Effect of microclimate, season and region on Sauvignon blanc grape composition and wine quality. S. Afr. J. Enol. Vitic. 20, 19-30.

Matthews, M.A. \& Anderson, M.M., 1988. Fruit ripening in Vitis vinifera L.: Responses to seasonal water deficits. Am. J. Enol. Vitic. 39, 313-320.

Maxa, E., Brandes, W. \& Schmuckenschlager, J., 1995. Untersuchungen zum Verlauf der Zucker-, Säure- und Mineralstoffgehalte während der Traubenreife bei den Sorten Grüner Veltliner und Rheinreisling. Mitt. Klosterneuburg 45, 42-48.

Myburgh, P.A., 1996. Response of Vitis vinifera L. cv. Barlinka/Ramsey to soil water depletion levels with particular reference to trunk growth parameters. S. Afr. J. Enol. Vitic. 17, 3-14.
Myburgh, P.A., 2003. Responses of Vitis vinifera L. cv. Sultanina to level of soil water depletion under semi arid conditions. S. Afr. J. Enol. Vitic. 24:16-24.

Myburgh, P.A., 2005. Water status, vegetative growth and yield of Vitis vinifera L. cvs. Sauvignon blanc and Chenin blanc in response to timing of irrigation during berry ripening in the Coastal region of South Africa. S. Afr. J. Enol. Vitic. 26, 59-67.

Myburgh, P.A., Van Zyl, J.L. \& Conradie, W.J., 1996. Effect of soil depth on growth and water consumption of young Vitis vinifera L cv. Pinot noir. S. Afr. J. Enol. Vitic. 18, 53-62.

Naor, A., Bravdo, B. \& Hepner, Y., 1993. Effect of post véraison irrigation level on Sauvignon blanc yield, juice quality and water relations. S. Afr. J. Enol. Vitic. $14,19-25$.

Schrader, U., Lemperle, E., Becker, N.J. \& Bergner, K.G., 1976. Der Aminosäure-, Zucker-, Säure- und Mineralstoffgehalt von Weinbeeren in Abhängigkeit vom Kleinklima des Standortes der Rebe. 3. Mitteilung: Säure- und Mineralstoffgehalt. Wein Wiss. 31, 160-175.

Smart, R.E. \& Coombe, B.G., 1983. Water relations of grapevines. In: Kozlowski, T.T. (ed.). Water deficits and plant growth, vol. VII. Academic Press, New York. pp. 137-196.

Spayd, S.E., Nagel, C.W. \& Edwards, C.G., 1995. Yeast growth in Riesling juice as affected by vineyard nitrogen fertilization. Am. J. Enol. Vitic. 46, 49-55.

Tromp, A. \& Conradie, W.J., 1979. An effective scoring system for sensory evaluation of experimental wines. Am. J. Enol. Vitic. 30, 278-283.

Van Zyl, J.L., 1984a. Interrelationships among soil water regime, irrigation and water stress in the grapevine (Vitis vinifera L.). Thesis, Stellenbosch University, Private Bag X1, 7602 Matieland (Stellenbosch), South Africa.

Van Zyl, J.L., 1984b. Response of Colombar grapevines to irrigation as regards quality aspects and growth. S. Afr. J. Enol. Vitic. 5, 19-28.

Van Zyl, J.L. \& Weber, H.W., 1977. Irrigation of Chenin blanc in the Stellenbosch area within the framework of the climate-soil-water-plant continuum. Proc. Int. Symp. Quality Vintage, Cape Town, South Africa. pp. 331-349.

Van Zyl, J.L. \& Weber, H.W., 1981. The effect of various supplementary irrigation treatments on plant and soil moisture relationships in a vineyard (Vitis Vinifera var. Chenin blanc). S. Afr. J. Enol. Vitic. 2, 83-99.

Van Zyl, J.L. \& Van Huyssteen, L., 1983. Soil and water management for optimum grape yield and quality under conditions of limited irrigation. Proc. 5th Austr, Wine Indus. Tech. Conf., 29 November - 1 December 1983, Perth. pp. 25-66.

Van Zyl, J.L. \& Fourie, A., 1988. Using crop factors and the Class A pan to estimate the irrigation requirements of vines. Farming in S. Afr. VORI 227/1988, ARC Infruitec-Nietvoorbij, Private Bag X5026, 7599 Stellenbosch, South Africa.

Williams, L.E. \& Matthews, M.A., 1990. Grapevines. In: Stewart, B.A. \& Nielsen, D.R. (eds). Irrigation of agricultural crops, Agronomy Monograph No. 30. ASA-CSSA-SSSA, Madison, pp. 1019-1055

Williams, L.E., Dokoozlian, N.K. \& Wample, E.R., 1994. Temperate crops. In: Schaffer, B. \& Anderson, P.C. (eds). Handbook of environmental physiology of fruit crops, Vol 1, CRC Press, Boca Raton, pp. 85-133. 